\title{
In vitro Gas Production, Methane Emission and Rumen Fermentation Characteristics with Increasing Roughage to Concentrate Ratios
}

\author{
Samir Attia Nagadi \\ Department of Arid Land Agriculture, Faculty of Meteorology, Environment and Arid Land \\ Agriculture, King Abdulaziz University, Jeddah, Saudi Arabia \\ dr_sameer6831@hotmail.com

\begin{abstract}
Effects of roughage to concentrate ratio on gas production (GP) and nutrient degradability were evaluated in vitro. Rations I: 0R:100C, II: 20R:80C, III: 40R:60C, IV: 60R:40C, V: 80R:20C and VI: 100R:0C were incubated for 24h. Concentrate (0R:100C) produced greater GP/gDM, TDOM and MCP. TDDM was higher for rations I to IV than V and VI. Roughage (100R:0C) had lower PF and higher $\mathrm{pH}$ and protozoal count with no VFA effect. of soluble substrate between microbial biomass production and fermentation waste products and are optimal for sheep nutrition.
\end{abstract} \\ Ration III and IV containing 60 and $40 \%$ concentrate, respectively exhibited balanced distribution
}

Keywords: Gas production, Methane, Roughage, Concentrate, Ammonia.

\section{Introduction}

Forage production in arid and semi-arid regions is low where producers in these parts of the world are raising their animals on cereals and/or concentrate mixtures, thus rations offered to animals mostly are unbalanced. Previous studies revealed that supplementation with diets high in concentrate: roughage $(\mathrm{C}: \mathrm{R})$ ratio may decrease the digestibility of nutrients (Castrillo et al., 1995). However, supplementation with high fibre diets with easily digestible carbohydrate and protein can increase the nutrient digestibility (Swanson et al., 2000 and Yang et al., 2000). It is well established that feeding concentrates promotes rapid growth of animals (McDonald et al., 1996), reduce ruminal methane emission, thereby lowering undesirable losses of energy leading to higher overall efficiency of utilization of dietary energy for body weight gain (Mandebvu and Galbraith, 1999). However, diets high in cereals reduce ruminal $\mathrm{pH}$ (Franzolin and Dehority, 1996), which may induce acidosis thereby causing reduced feed intake and nutrient absorption as well as retarded animal performance (Owens et al., 1998). Shem et al. (2003) and Tessema and Baars, (2004) reported that concentrate supplements improved the utilization of poor feeds by ruminants by improving digestibilities of dry matter, organic matter and crude protein by stimulating rumen fermentation. Therefore, there may be an optimal concentrate supplementation level for a given kind of roughage, which allows the animal to use the nutrients in the roughage most efficiently (Liu et al., 2005). Optimum roughage to concentrate ratio is crucial for proper rumen fermentation and availability of nutrients. Therefore, the objective of this work was to 
evaluate the effect of different ratios of roughage to concentrate intended for feeding sheep in arid regions on gas production (GP), methane emission, and nutrient degradability in vitro.

\section{Materials and Methods}

\subsection{Feeds and Experimental Rations}

Alfalfa hay was used as the roughage (R) and a wheat-based commercial concentrate mixture manufactured by the Saudi Grains Organization (SAGO), Jeddah, KSA was used as concentrate $(\mathrm{C})$ to formulate the following the six experimental rations: I (concentrate, 0R:100C), II (20R:80C), III (40R:60C), IV (60R:40C), V (80R:20C) and VI (roughage, 100R:0C).

\subsection{Proximate Chemical Analysis}

The dried samples were ground to pass a $1 \mathrm{~mm}$ screen using Wiley mill. Feed analyses were performed according to AOAC (2006). Dry matter contents of feeds were determined by drying at $135^{\circ} \mathrm{C}$ for $2 \mathrm{~h}$. Organic matter was determined as the weight loss during ashing at $550^{\circ} \mathrm{C}$ for $2 \mathrm{~h}$. Contents of nitrogen $(\mathrm{N})$ were determined by the kjeldahl method, and crude protein $(\mathrm{CP})$ was calculated as $6.25 \times \mathrm{N}$ content. Ether extract was determined according to AOAC (2006). The neutral detergent fibers (NDF) and acid detergent fiber (ADF) were determined using the procedures of Van Soest et al. (1991). No sodium sulfite or $\alpha$ - amylase was used in the procedure for NDF determination. Both NDF and ADF are expressed without residual ash (Table 1).

\subsection{Inoculums Donors and Preparations}

Three rumen-cannulated adult rams of body weight $49.0 \pm 2.3 \mathrm{~kg}$ were used as inoculum donors. Both solid and liquid rumen contents were collected separately before morning feeding through the cannula using a stainless steel probe $(2.5 \mathrm{~mm}$ screen) attached to a large capacity syringe. Liquids and solids were placed in prewarmed $\left(39^{\circ} \mathrm{C}\right)$ insulated flasks and transported under anaerobic conditions to the laboratory. Pooled rumen contents $(50: 50 \mathrm{v} / \mathrm{v})$ were squeezed through four layers of cheese-cloth and kept in a water bath at $39^{\circ} \mathrm{C}$ saturated with $\mathrm{CO}_{2}$ until inoculation took place.

\subsection{In vitro Gas Production and Methane Production}

The in vitro gas production (GP) assay was carried out as described by Theodorou et al. (1994) but was adapted to the semiautomatic system using a pressure transducer and data logger (GN200, Sao Paulo, Brazil) in $120 \mathrm{ml}$ serum bottles incubated at $39^{\circ} \mathrm{C}$ for 24 h. Ground samples (0.3g as-fed) were incubated in $120 \mathrm{ml}$ serum bottles along with $15 \mathrm{ml}$ mixed rumen fluid and $30 \mathrm{ml}$ of MB9 incubation medium. The composition of MB9 was $\mathrm{NaCl}(2.8 \mathrm{~g}), \mathrm{CaCl}_{2}(0.1 \mathrm{~g}), \mathrm{MgSO}_{4} .7 \mathrm{H}_{2} \mathrm{O}$ (0.1g), $\mathrm{KH}_{2} \mathrm{PO}_{4}(2.0 \mathrm{~g})$ and $\mathrm{Na}_{2} \mathrm{HPO}_{4}(6.0 \mathrm{~g})$ per 1.0 litre of distilled water. Then the $\mathrm{pH}$ was adjusted to 6.8 and $\mathrm{CO}_{2}$ was flushed for 30 min (Onodera and Henderson, 1980). After filling, bottles were closed with rubber stoppers, shaken and placed in the incubator at $39^{\circ} \mathrm{C}$. The bottles were shaken manually after recording the gas headspace pressure (GP) at $3,6,9,12$ and $24 \mathrm{~h}$ incubation using a pressure transducer. Gas production was calculated by the following equation: $\mathrm{V}=7.365 \times \mathrm{p}(\mathrm{n}=500$; r2 = 0.99; unpublished data) where: $\mathrm{V}$ is gas volume (ml); $\mathrm{p}$ is measured pressure (psi). Four runs of GP were used for each assay. Measurements of GP were performed in quadruplicate. Each run included four bottles containing buffered rumen fluid without substrate (blank), four bottles containing substrate without additive (control), and four bottles containing substrate for each treatment. 
The gas values were expressed as $\mathrm{ml}$ per $\mathrm{g}$ of incubated DM.

\subsection{Methane Emission Analyses}

Representative gas samples were collected from the bottles by a syringe $(2 \mathrm{ml})$ each time and accumulated in vacutainer tubes (10ml) five times at $3,6,9,12,24 \mathrm{~h}$ incubation. The methane was determined by gas chromatography (Model 7890, Agilent Technologies, Inc., Colorado 80537, USA) with three-valve system using $1 / 8$ inch packed columns having early back flush of the C6 components and equipped with a thermal conductivity detector. Separation was achieved using micro packed column with helium as carrier gas and a flow rate of $28.0 \mathrm{ml} / \mathrm{min}$. The detector and column temperatures were $250^{\circ} \mathrm{C}$ and $60^{\circ} \mathrm{C}$, respectively. The test of linearity and calibration were accomplished using a standard gas curve in the range of probable concentrations of the samples. The methane production at the end of incubation was calculated as described by Tavendale et al. (2005): $\mathrm{CH}_{4}, \mathrm{ml}=$ (total gas volume + headspace) $\times \mathrm{CH}_{4}$ concentration. Both GP and $\mathrm{CH}_{4}$ were expressed as $\mathrm{ml} / \mathrm{g} \quad \mathrm{DM}$ and calculated by correcting the values of total gas production and incubated or truly degraded organic matter for the corresponding blank.

\subsection{Rumen Degradability and Fermentation Characteristics}

After termination of the incubation (24h), the contents of two bottles were used to determine the true digestibility of dry matter (DM) and OM (TDDM, TDOM) with 50ml neutral detergent solution and refluxed for $3 \mathrm{hrs}$ at $105^{\circ} \mathrm{C}$. The bottles content were filtered in pre-weighed crucible, washed with hot water then with acetone and the residual DM and ash were determined according to Blümmel and Becker (1997). The partitioning factor (PF) was calculated as the ratio of TDOM (mg) and gas volume ( $\mathrm{ml}$ in 24h) (Blümmel et al.,
1997). The content of each bottle were transferred to a centrifuge tube and centrifuged at $3000 \mathrm{rpm}$ for $15 \mathrm{~min}$. Five millilitres from the supernatant were transferred into $10 \mathrm{ml}$ glass bottle and stored at $-20^{\circ} \mathrm{C}$ until analysed for NH3-N and short chain fatty acids (SCFA). Ammonia concentration was calorimetrically analysed using a commercial Kit (Bio diagnostic Company, Egypt). Protozoa were counted microscopically following the procedure described by Kamra et al. (1991).

\subsection{Statistical Analyses}

The experimental design used in this study was the completely randomized design (CRD). Statistical analyses of the in vitro data were analysed by the generalized linear model procedure (SAS, 2002). The following model was assumed: $Y i j=\mu+\mathrm{Ti}+$ eij where: $\mu$ is the overall mean, $\mathrm{Ti}$ is the treatment, eij is the random error term. Proper contrasts comparisons were used to determine the linear, quadratic and cubic variables response to increasing levels of the concentrate in the diet. Differences between treatments were declared significant at 0.05 level using the revised LSD for multiple comparisons.

\section{Results}

Mean values of the proximate analysis rations I (concentrate, 0R:100C), II (20R:80C), III (40R:60C), IV (60R:40C), V (80R:20C) and VI (roughage-alfalfa hay, 100R:0C) on dry matter basis, are presented in Table 1. Roughage (100R:0C) as a good quality alfalfa hay had higher crude protein $(20.19 \%)$ and ash $(10.74 \%)$ content compared to concentrate (17.93 and $6.61 \%$, respectively). Similarly, was the crude protein and ash contents in rations II to $\mathrm{V}$ following similar trend with the increase in roughage percentage replacing concentrate in the rations. Higher values of nutrients detergent fiber (NDF), acid detergent fiber (ADF), acid lignin fiber (ADL) and cellulose $(48.56,32.56,6.91$ and $23.85 \%$, 
respectively) were observed in the roughage compared to the concentrate $(32.65,8.76,2.23$ and $6.53 \%$, respectively).

\subsection{In vitro Rumen Degradability and Fermentation Characteristics}

The effects of tested rations on cumulative in vitro gas production (IVGP), TDDM, TDOM and partitioning factor (PF) after incubation for $24 \mathrm{~h}$. in vitro are presented in Table 2. The addition of roughage was found to be accompanied with decreasing gas production $(\mathrm{ml} / \mathrm{gDM})$ as compared to that of concentrate ration. No significant $(P=0.16$ and $P=0.15)$ differences were observed among rations in their GP per g TDDM and TDOM, respectively. Truly digestible dry matter (TDDM) was significantly $(P<0.01)$ high for ration I, concentrate (0R:100C) and remained high even with $60 \%$ roughage replacing concentrate in ration IV (60R:40C) then started to decrease in ration V (80R:20C) containing $80 \%$ hay and ration VI (roughage alone). Inclusion of roughage at $60 \%$ in the rations improved TDDM in a linear $(P<0.01))$ then quadratic $(\mathrm{P}=0.01)$ fashion. However, inclusion of roughage at any tested ratio (20, 40,60 and $80 \%$ ) decreased the truly digestible organic matter (TDOM) in a linear $(P<0.01)$ then quadratic $(P=0.01)$ fashions where the concentrate (ration I) recording the highest TDOM and the roughage (ration VI) recording the lowest. All rations including concentrate (ration I) and rations containing increasing ratios of concentrate (rations II, III, IV and V) had higher $(P<0.01)$ partitioning factor than alfalfa hay alone (ration VI, roughage alone). The change in PF after inclusions of $(20,40$, 60 , and $80 \%)$ ratios of concentrate was quadratic $(P<0.01)$.

\subsection{In vitro Rumen Methane Emission}

The effects of tested rations on cumulative methane production, ammonia, microbial protein production and $\mathrm{pH}$ after incubation for $24 \mathrm{~h}$ in vitro are presented in Table 3. No significant differences were observed among all rations from I to VI in their methane gas emission per $\mathrm{g} \mathrm{DM}$, TDDM,TDOM and ammonia $\mathrm{N}\left(\mathrm{CH}_{3}-\mathrm{N}\right.$, $\mathrm{mg} / 100 \mathrm{ml}$ ) except ration VI (0C:100R) that contains $100 \%$ roughage produced slightly less methane $(29.6 \mathrm{~m} / \mathrm{g} \mathrm{DM})$ (Table 3). In contrast to methane and ammonia production, increasing the ratio of roughage in the rations decreased $(P<0.01) \mathrm{MCP}(\mathrm{g} / \mathrm{kg}$ DOM) linearly $(P<0.01)$ and quadraticaly $(P<0.01)$ compared to concentrate. Rations II, III and IV containing 20, 40 and $60 \%$ roughage, respectively produced significantly less MCP than ration $\mathrm{I}$ (concentrate, 0R:100C) and significantly higher than rations $\mathrm{V}$ and VI that contained 80 and $100 \%$ roughage. The inclusion of roughage increased significantly $(P<0.01)$ the $\mathrm{pH}$ values in ration II $(5.5)$, III (5.60), IV (5.70), V (5.80) and VI (5.80) compared to (5.48) for the concentrate (ration I). The increased $\mathrm{pH}$ values followed a linear $(P<0.01)$ then quadratic $(P<0.01)$ patterns with the inclusion of roughage in rations.

\subsection{Total Volatile Fatty Acids (VFA) and Protozoal Growth}

In vitro production of total volatile fatty acids (VFA) and protozoal count are presented in Fig. 1. No differences in the concentrations of total volatile fatty acids (meq/100ml) were found after fermentation of the six experimental rations in vitro (Fig. 1). However, significantly $(P<0.05)$ lowest protozoal growth was recorded with concentrate ration, whereas protozoal growth increased significantly as percentages of roughage increased in the ration.

\section{Discussion}

\subsection{In vitro Rumen Methane Emission Characteristics}

Gas production is the result of fermentation of carbohydrates to volatile fatty 
acids i.e., acetate, propionate and butyrate, and GP from protein fermentation is relatively lesser compared to carbohydrates (Makkar et al., 1995). The higher GP observed in ration I (0R:100C) might be due to increased production of propionate as $\mathrm{CO}_{2}$ is produced when propionate is made by ruminal bacteria via the succinate: propionate pathway (Seshaiah et al., 2014). Also increased GP after incubation of ration I (concentrate, 0R:100C) can be attributed to increased numbers of starch fermenting bacteria due to abundance of soluble carbohydrates (starch). Decreased GP from rations II to VI containing $20,40,60,80$ and $100 \%$ roughage might be considered a positive effect as the inclusion of roughage content in the rations could increase utilization of rations nutrients, decrease GP, and presumably reduce the risk of bloat in vivo. The $\mathrm{pH}$ value (5.48) was lower when inoculum was incubated with concentrate and was gradually increased with the gradual increase in roughage ratio replacing concentrate in the inoculum. This could be due to that roughage (alfalfa hay) contained more NDF, ADF and cellulose than concentrate (maximum concentrate, 100\%) which could explains the higher gas production when roughage fraction was minimal $(0 \%)$. The $\mathrm{pH}$ value measurements can be used as a tool to evaluate the fermentation process in the rumen (Kumar et al., 2013). The $\mathrm{pH}$ value decreased as the amount of concentrate mix in the ration was maximal (100\%) which was similar to findings reported by Kumar et al. (2013). In our study, $\mathrm{pH}$ values ranged from 5.48 to 5.8, was relatively stable, and were greater than 5.0 to 5.5 range suggested by Hoover (1986) at which ruminal microbial bioactivity was negatively affected.

The truly digestible dry matter (TDDM) and truly digestible organic matter (TDOM) were reduced significantly $(P<0.05)$ by increasing roughage level (Table 3 ). The decrease in degradability in roughage content can be due to more lignin content in roughage compared to concentrate (Table 2). It is generally agreed that lignin content of forages is negatively correlated with extent of digestion (Jung, 1997). The lignin supressing effect is probably resulting from a reduction in attachment of ruminal microbes to feed particles and inhibition of microbial growth and microbial enzyme activity (McSweeny, 2001). Others (Reddy et al., 2016) reported that in vitro OMD and TDOM increased linearly with the increase of concentrate proportion in the diet. They attributed such increase to gradual decrease in cellulose and lignin in their diets, which act as a limiting factor to lowering digestibility (Al-Masri, 2009 and Kumari et al., 2012). The increase of in-vitro OMD in rations I, II, III and IV containing 100, 80, 60 and 40\% concentrate, respectively (Table 3 ) might be due to the increase of readily available energy and protein contents of these rations which might have improved microbial growth and fermentation (Chatterjee et al., 2006). Therefore, ration IV (60R:40C) improved TDDM similar to ration I (concentrate, 0R:100C) and its effect on OMD was intermediate.

More importantly, rations III (60\% concentrate) and IV (40\% concentrate) are considered the optimal rations that minimized energy wastage in the form of GP with DM and $\mathrm{OM}$ values remaining similar to that of ration II with higher concentrate (20R:80C). The levels of NH3-N concentrations ranged from 18.55 to $20.53 \mathrm{mg} / \mathrm{dl}$ which was similar to that by Wanapat and Pimpa (1999) (15-30.0 $\mathrm{mg} / \mathrm{dl})$ in the rumen and Polyorach et al. (2014) in vitro. An increase in the nitrogenous concentrate supply generally increases $\mathrm{NH} 3-\mathrm{N}$ content in rumen juice, however no significant difference was found between concentrate mix and hay regarding $\mathrm{NH} 3-\mathrm{N}$ content but 
concentrate mix had higher microbial $\mathrm{CP}$ than hay alone. In the meantime, increased concentrate ratio was associated with more MCP production. In case of rations high in concentrate, energy availability was probably higher than rations with less concentrate. Microbes in rations high in concentrate would require more NH3-N to sustain their growth, which would decrease NH3-N to levels similar to rations low in concentrate, which was probably the case in the current study. Microbial CP concentration as a function of microbial biomass explains the sustained higher growth rate of microbes in high concentrate rations in the present study. During incubation, the liberated ammonia will be incorporated into microbial protein synthesis, but this incorporation depends on synchronization between availability of nitrogen and energy (Thirumalesh and Krishnamoorthy, 2013). Therefore, partitioning factor (PF) provides a meaningful information for prediction of microbial biomass and available $\mathrm{CP}$ in the rumen (Thirumalesh and Krishnamoorthy, 2013). They also, reported a positive correlation between microbial biomass and PF of total mixed rations. $\mathrm{PF}$ is an index of the distribution of truly degraded substrate between microbial biomass and fermentation waste products, as reported by Thirumalesh and Krishnamoorthy (2009). This mean that higher PF indicate that more of truly degraded substrate was converted to microbial protein synthesize. Therefore, all ration except roughage alone had elevated $\mathrm{PF}$ and the later (roughage alone) had the lowest MCP. More importantly, ration III $(60 \% \mathrm{C})$ and IV $(40 \% \mathrm{C})$ had balanced distribution of soluble substrate between microbial biomass production and fermentation waste products.

The total VFA was not significantly affected by increased levels of concentrate in the rations. However, others (Suharti et al.,
2011 and Kumar et al., 2013) reported that total VFA was significantly affected by forage to concentrate ratio in the diet. Total protozoa count in ruminal fluid generally increases with the addition of concentrate to forage in the diet (Franzolin and Dehority, 1996 and Saini et al., 2012). Further, feeding high-grain diets can result in reduced protozoa numbers or even defaunation (Hristov et al., 2001). Ramos et al. (2009) reported that increasing concentrate from 30 to $70 \%$ in the diet with alfalfa hay as a forage increased protozoa numbers by $48 \%$, but this effect was not observed when grass hay was used as a forage. In our study, total protozoal count was lowest in $100 \%$ concentrate (ration I) and protozoal count increased gradually with inclusions of more roughage in the rations with highest count recorded in ration VI (Roughage, 100R:0C). In agreement with the findings reported by Franzolin and Dehority (1996) and Hristov et al. (2001) where high-grain diets may lower the $\mathrm{pH}$ values and greater amounts of starch in high concentrate rations may produce greater lactic acid concentrations (Slyter, 1976) and hence lower $\mathrm{pH}$ measurements concurrent with the $\mathrm{pH}$ values observed in the current study negatively affecting protozoal growth.

Concentrate feeding has been shown to reduce methane $\left(\mathrm{CH}_{4}\right)$ output by reducing the protozoal population (Van Soest, 1982 and Iqbal et al., 2008). Nevertheless, no difference in $\mathrm{CH}_{4}$ production among the incubated rations with different roughage to concentrate ratios in the current study.

\section{Conclusions}

Considerable attention should be paid during formulation of sheep rations in order to produce rations with optimum roughage to concentrate ratio for efficient nutrient utilization. Based on the results obtained in the present study, ration III and IV containing 60 and $40 \%$ concentrate, respectively exhibited 
balanced distribution of soluble substrate between microbial biomass production and fermentation waste products and can be considered optimal rations for sheep raised under harsh nutritional and climatic conditions.

Table 1. Proximate analyses of the tested rations on dry matter basis.

\begin{tabular}{lllllll}
\hline \multirow{2}{*}{ Items } & Rations & & & & \\
\cline { 2 - 7 } & I & II & III & IV & V & VI \\
\hline Organic matter, \% & 93.39 & 92.65 & 91.80 & 91.10 & 90.15 & 89.26 \\
Ash,\% & 6.61 & 7.35 & 8.20 & 8.90 & 9.85 & 10.74 \\
Crude protein,\% & 17.93 & 19.25 & 17.71 & 20.56 & 20.68 & 20.19 \\
Ether extract,\% & 5.39 & 5.64 & 5.02 & 4.40 & 5.75 & 4.31 \\
Neutral detergent fiber,\% & 32.65 & 34.75 & 38.64 & 41.55 & 44.63 & 48.56 \\
Acid detergent fiber,\% & 8.76 & 13.43 & 19.51 & 23.41 & 28.20 & 30.77 \\
Acid detergent lignin,\% & 2.23 & 3.23 & 4.31 & 5.30 & 7.14 & 6.91 \\
Hemicellulose,\% & 23.89 & 21.32 & 19.13 & 18.14 & 16.43 & 17.80 \\
Cellulose,\% & 6.53 & 10.19 & 15.20 & 18.11 & 21.06 & 23.85 \\
\hline
\end{tabular}

Roughage: alfalfa hay C: Concentrate mix manufactured by Saudi Grains Organization (SAGO), heat-based.

Table 2. In vitro gas production (IVGP) per dry matter (DM), truly digestible dry matter (TDDM), truly digestible organic matter (TDOM) and partitioning factor (PF) of the tested rations.

\begin{tabular}{|c|c|c|c|c|c|c|}
\hline \multirow{2}{*}{ Rations } & \multicolumn{3}{|c|}{ IVGP (ml/g) } & \multirow{2}{*}{$\begin{array}{l}\text { TDDM } \\
\text { (g/100g) }\end{array}$} & \multirow{2}{*}{$\begin{array}{l}\text { TDOM } \\
(\mathrm{g} / 100 \mathrm{~g})\end{array}$} & \multirow{2}{*}{$\begin{array}{l}\text { PF } \\
(\mathrm{mg} / \mathrm{ml})\end{array}$} \\
\hline & DM & TDDM & TDOM & & & \\
\hline I, (0R:100C) & $134.4^{\mathrm{a}}$ & 145.3 & 157.7 & $88.85^{\mathrm{a}}$ & $82.23^{\mathrm{a}}$ & $3.90^{\mathrm{a}}$ \\
\hline II, (20R:80C) & $113.4^{\mathrm{b}}$ & 134.0 & 140.8 & $86.20^{\mathrm{a}}$ & $79.10^{\mathrm{b}}$ & $3.38^{\mathrm{a}}$ \\
\hline III, (40R:60C) & $102.2^{\mathrm{b}}$ & 120.8 & 131.7 & $84.90^{\mathrm{a}}$ & $77.65^{\mathrm{b}}$ & $3.72^{\mathrm{a}}$ \\
\hline IV, (60R:40C) & $100.4^{\mathrm{b}}$ & 120.2 & 131.0 & $85.20^{\mathrm{a}}$ & $78.13^{\mathrm{b}}$ & $3.61^{\mathrm{a}}$ \\
\hline $\mathrm{V},(80 \mathrm{R}: 20 \mathrm{C})$ & $101.6^{\mathrm{b}}$ & 132.9 & 147.0 & $76.90^{\mathrm{b}}$ & $68.85^{\mathrm{c}}$ & $3.70^{\mathrm{a}}$ \\
\hline VI, (100R:0C) & $110.3^{\mathrm{b}}$ & 137.5 & 150.7 & $75.03^{\mathrm{b}}$ & $66.63^{\mathrm{d}}$ & $2.70^{\mathrm{b}}$ \\
\hline SEM & 3.17 & 4.27 & 4.83 & 1.30 & 1.20 & 0.11 \\
\hline$P$ values & $<0.01$ & 0.16 & 0.15 & $<0.01$ & $<0.01$ & $<0.01$ \\
\hline Linear & 0.76 & 0.22 & 0.08 & 0.01 & $<0.01$ & 0.07 \\
\hline Quadratic & 0.67 & 0.54 & 0.74 & 0.01 & 0.01 & $<0.01$ \\
\hline Cubic & 0.09 & 0.11 & 0.15 & 0.59 & 0.09 & 0.11 \\
\hline
\end{tabular}

Means in the same column bearing different letters differ significantly. SEM = standard error of the mean.

Table 3. In vitro methane emission per dry matter, (DM), truly digestible dry matter (TDDM), truly digestible organic matter (TDOM), CH3-N (ammonia nitrogen), microbial protein production and $\mathrm{pH}$ of the tested rations.

\begin{tabular}{|c|c|c|c|c|c|c|}
\hline \multirow[b]{2}{*}{ Rations } & \multicolumn{3}{|c|}{ Methane, $\mathrm{ml} / \mathrm{g}$} & \multirow[b]{2}{*}{$\begin{array}{l}\mathrm{CH}_{3}-\mathrm{N} \\
(\mathrm{mg} / 100 \\
\mathrm{ml})\end{array}$} & \multirow[b]{2}{*}{$\begin{array}{l}\text { MCP } \\
(\mathrm{g} / \mathrm{kg} \\
\mathrm{DOM}) \\
\end{array}$} & \multirow{2}{*}{ pH } \\
\hline & DM & TDDM & TDOM & & & \\
\hline $\mathrm{I}, \quad(0 \mathrm{R}: 100 \mathrm{C})$ & 36.4 & 40.8 & 44.3 & 19.80 & $158.73 a$ & $5.48^{d}$ \\
\hline II, (20R:80C) & 36.1 & 36.4 & 39.7 & 18.55 & $152.68^{\mathrm{b}}$ & $5.50 \mathrm{c}$ \\
\hline III, (40R:60C) & 31.4 & 36.9 & 40.4 & 19.83 & $149.88^{b}$ & $5.60^{\mathrm{b}}$ \\
\hline IV, (60R:40C) & 33.7 & 39.4 & 43.1 & 19.28 & $150.78^{b}$ & $5.70^{\mathrm{b}}$ \\
\hline V, (80R:20C) & 30.9 & 40.0 & 45.2 & 20.53 & $132.88^{\mathrm{c}}$ & $5.80^{\mathrm{a}}$ \\
\hline VI, (100R:0C) & 29.6 & 39.4 & 44.7 & 19.98 & $128.58^{\mathrm{d}}$ & $5.80^{\mathrm{a}}$ \\
\hline SEM & 1.15 & 1.3 & 1.6 & 0.44 & 2.3 & 0.03 \\
\hline$P$ values & 0.28 & 0.90 & 0.89 & 0.89 & $<0.01$ & $<0.01$ \\
\hline Linear & 0.15 & 0.35 & 0.24 & 0.34 & $<0.01$ & $<0.01$ \\
\hline Quadratic & 0.54 & 0.51 & 0.72 & 0.70 & $<0.01$ & $<0.01$ \\
\hline Cubic & 0.25 & 0.78 & 0.80 & 0.99 & 0.08 & $<0.01$ \\
\hline
\end{tabular}

Means in the same column bearing different letters differ significantly. SEM = standard error of the mean. 

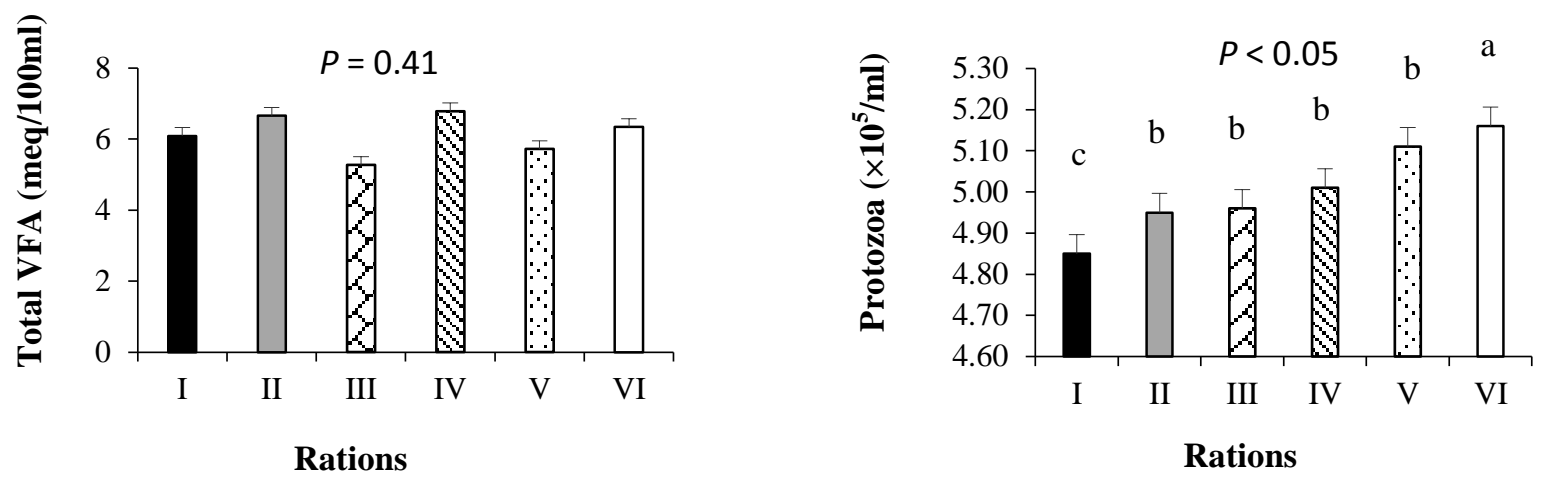

Fig. 1. In vitro production of total volatile fatty acids (VFA, meq/dl) and protozoa concentrations (105/ml) in rations I (concentrate, 0R:100C), II (20R:80C), III (40R:60C), IV (60R:40C), V (80R:20C) and VI (roughage, 100R: 0C) after 24 hrs of incubation in vitro.

\section{References}

A.O.A.C. (2006). Official Methods of Analysis of AOAC International (2006). 20th ed. AOAC International, Arlington, VA, USA.

Al-Masri, M. R. (2009). An in vitro nutritive evaluation and rumen fermentation kinetics of Sesbania Aculeate as affected by harvest time and cutting regimen. Trop. Anim. Health Prod., 41: 1115-1126.

Blümmel, M. and Becker, K. (1997). The degradability characteristics of fifty-four roughages and roughage neutral detergent fiber as described by in vitro gas production and their relationship to voluntary feed intake. Brit. J. Nut., 77: 757-768.

Blümmel, M., Steinga, H. and Becker, K. (1997). The relationship between in vitro gas production, in vitro microbial biomass yield and $\mathrm{N}$ incorporation and its implications for the prediction of voluntary feed intake of roughages. Brit. J. Nut., 77: 911-921.

Castrillo, C., Fondevila, M., Guada, J. A. and de Vega, A. (1995). Effect of ammonia treatment and carbohydrate supplementation on the intake and digestibility of barley straw diets by sheep. Anim. Feed Sci. Technol., 51 (1-2): 73-90.

Chatterjee, P.N., Kamra, D.N. and Agarwal, N. (2006). Effect of roughage source, protein and energy levels on in vitro fermentation and methanogenesis. Ind. J. Anim. Nutr., 23: 72-77.

Franzolin, R. and Dehority, B. A. (1996). Effect of prolonged high concentrate feeding on ruminal protozoa concentrations. J. Anim. Sci., 74: 2803-2809.

Hoover, W. H. (1986). Chemical factors involved in ruminal fiber digestion. J. Dairy Sci., 69: 2755-2766.

Hristov, A. N., Ivan, M., Rode, L. M. and McAllister, T. A. (2001). Fermentation characteristics and ruminal ciliate protozoal populations in cattle fed medium- or highconcentrate barley-based diets. J. Anim. Sci., 79: 515-524.
Iqbal, M. F., Cheng, Y. F., Zhu, W. Y. and Zeshan, B. (2008). Mitigation of ruminant methane production, current strategies, constraints and future options. World $J$. Microbiol. Biotechnol., 24: 2747-2755.

Jung, H.G., Mertens, D.R. and Payne, A.J. (1997). Correlation of acid detergent lignin and Klason lignin with digestibility of forage dry matter and neutral detergent fiber. J. Dairy Sci., 80: 1622-1628.

Kamra, D. N., Sawal, R. K., Pathak, N. N., Kewalramani, N. and Agarwal, N. (1991). Diurnal variation in ciliate protozoa in the rumen of blackbuck (Antilopecervicapra). Lett. Appl. Microbiol., 13: 165-167.

Kumar, S., Dagar, S. S., Sirohi, S. K., Padhyay, R. C. and Puniya, A. K. (2013). Microbial profiles, in vitro gas production and dry matter digestibility based on various ratios of roughage to concentrate. Ann. Microb., 63: 541545.

Kumari, N., Ramana, Y. R., Blummel, M. and Monika, T. (2012). Optimization of roughage to concentrate ratio in sweet sorghum bagasse Based complete ration for efficient microbial biomass production in sheep using in vitro gas technique. Intl. J. Pharm. Biosci., 3: 247-257.

Liu, X., Wang, Z. and Lee, F. (2005). Influence of concentrate level on dry matter intake, $\mathrm{N}$ balance, nutrient digestibility, ruminal outflow rate, and nutrient degradability in sheep. Small Ruminant Research, 58: 5562.

Makkar, H.P.S., Blummel, M. and Becker, K. (1995). Formation of complexes between polyvinyl pyrrolidones or polyethylene glycols and tannins and their implications in gas production and true digestibility in in vitro techniques. Brit. J. Nutr., 73: 897-933.

Mandebvu, P. and Galbraith, H. (1999). Effect of sodium bicarbonate supplementation and variation in the proportion of barley and sugar beet pulp on growth performance and rumen, blood and carcass characteristics 
in young entire lambs. Anim. Feed Sci. Technol., 82: 3749.

McDonald, P., Edward, R.A., Greenhalgh, J.F.D.F. and Morgan, C.A. (1996). Animal Nutrition. Longman Scientific and Technical, Harlow, UK.

McSweeny, C.S., Palmer, B., McNeill, D.M., and Krause, D.O. (2001). Microbial interactions with tannins: nutritional consequences for ruminants. Anim. Feed Sci. and Technol., 91: 83-93.

Onodera, R. and Henderson, C. (1980). Growth factors of bacterial origin for the culture of the rumen oligotrich protozoon, Entodinium caudatum. J. Appl. Bacteriol., 48: 125-134.

Owens, F. N., D. S. Secrist, W. J. Hill, and Gill, D. R. (1998). Acidosis in Cattle: A Review. J. Anim. Sci., 76: 275-286.

Polyorach, S., Wanapat, M. and Cherdthong, A. (2014). Influence of Yeast Fermented Cassava Chip Protein (YEFECAP) and Roughage to Concentrate Ratio on Ruminal Fermentation and Microorganisms Using In vitro Gas Production Technique. Asian Australas. J. Anim. Sci., 27: $36-45$

Ramos, S., Tejido, M. L., Martinez, M. E., Ranilla, M. J. and Carro. M. D. (2009). Microbial protein synthesis, ruminal digestion, microbial populations, and nitrogen balance in sheep fed diets varying in forage to-concentrate ratio and type of forage. J. Anim. Sci., 87: 2924-2934.

Reddy, Y. R., Nalini Kumari, N., Monika, T. and Sridhar, K. (2016). Evaluation of optimum roughage to concentrate ratio in maize stover based complete rations for efficient microbial biomass production using in vitro gas production technique. Veterinary World, 9(6): 611-615.

Saini J. K., Hundal J. S., Wadhwa M. and Bakshi M. P. S. (2012). Effect of Roughage to Concentrate Ratio in the Diet on the Rumen Environment and Nutrient Utilization in Goat and Sheep. Ind. J. of Anim. Nutr., 29 (4): 333-338.

Seshaiah, C.V., Reddy, Y.R., Rao, S.J. and Srivani, M. (2014). Prediction of optimum roughage to concentrate ratio in sweet sorghum (Sorghum bicolor L. Moench) bagasse based total mixed ration for buffaloes using in vitro gas technique. J. Adv. Vet. Anim. Res., 1: 224-227.

Shem, M.N., Mtengeti, E.J., Luaga, M., Ichinohe, T. and Fujihara, T. (2003). Feeding value of wild Napier grass (Pennisetum macrourum) for cattle supplemented protein/or energy rich supplements. Anim. Feed Sci. Technol., 108: 15-25.

Slyter, L. L. (1976). Influence of acidosis on rumen function. J. Anim. Sci., 43,910-929.
Suharti, S., Astuti, D. A., Wina, E. and Toharmat. T. (2011). Rumen microbial population in the in vitro fermentation of different ratios of forage and concentrate in the presence of whole lerak (Sapindus rarak) fruit extract. Asian Australas. J. Anim. Sci., 24: 1086-1091.

Swanson, K. C., Caton, J. S., Redmer, D. A., Burke, V. I. and Reynolds, L. P. (2000). Influence of undegraded intake of protein on intake, digestion, serum hormones and metabolites, and $\mathrm{N}$ balance in sheep. Small Rumin. Res. 35: 225-233.

Tavendale, M. H., Meagher, L. P., Pacheco, D., Walker, N., Attwood, G. T. and Sivakumaran, S. (2005). Methane production from in vitro rumen incubations with Lotus pedunculatus and Medicago sativa, and effects of extractable condensed tannin fractions on methanogenesis. Anim. Feed Sci. Technol., 123: 403-419.

Tessema, Z. and Baars, R. M. T. (2004). Chemical composition, in vitro dry matter digestibility and ruminal degradation of Napier grass (Pennisetum purpureum (L.) Schumach.) mixed with different levels of Sesbania seban (L.) merr. Anim. Feed Sci. Technol. 117: 29-41.

Theodorou, M. K., Williams, B. A., Dhanoa, M. S., McAllan, A. B. and France, J. (1994). A simple gas production method using a pressure transducer to determine the fermentation kinetics of ruminant feeds. Anim. Feed Sci. Technol., 48: 185-197.

Thirumalesh, T. and Krishnamoorthy, U. (2013). Rumen microbial biomass synthesis and its importance in ruminant production. Int. J. Livest. Res., 3: 5-26.

Thirumalesh T. and Krishnamoorthy U. (2009). Effect of diets differing in partitioning factor on intake, digestibility and nitrogen metabolism in ram lambs. Anim. Nutr. Feed Technol. 9:11-20.

Van Soest, P. J. (1982). Nutritional ecology of the ruminant. $\mathrm{O}$ and $\mathrm{B}$ Books Inc, Corvallis.

Van Soest, P. V., Robertson, J. and Lewis, B. (1991). Methods for dietary fiber, neutral detergent fiber, and nonstarch polysaccharides in relation to animal nutrition. $J$. dairy Sci., 74: 3583-3597.

Wanapat, M. and Pimpa, O. (1999). Effect of ruminal NH3$\mathrm{N}$ levels on ruminal fermentation, purine derivatives, digestibility and rice straw intake in swamp buffaloes. Asian-Aust. J. Anim. Sci., 12: 904-907.

Yang, W. P., Yue, W. B. and Dong, Y. Z. (2000). The influence of concentrate supplementation on nutrient digestibility and growth performance of sheep based on stalk diets. Chin. J. Anim. Sci., 136: 5-7. 
إنتاج الغاز التراكمي والميثان وخصائص تخمر الكرش معمليًا بإضافة نسب متزايدة من

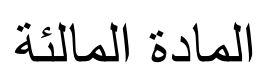

\section{سمير عطية نقادي}

قسم زراعة الدناطق الجافة، كلية الأرصاد والبيئة وزراعة الدناطق الجافة، جامعة الدلك عبد العزيز، جدة، المدلكة العربية السعودية dr_sameer6831@hotmail.com

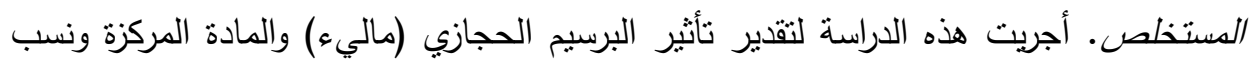

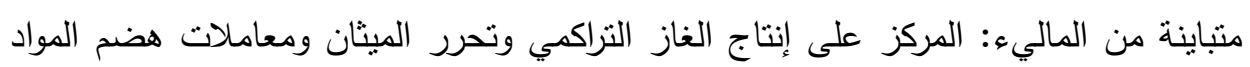

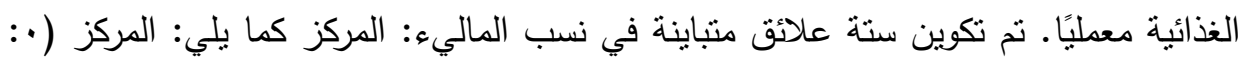

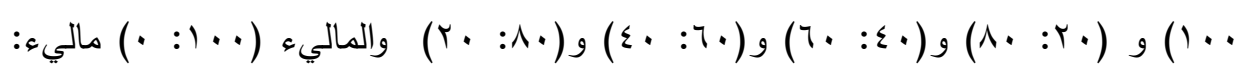

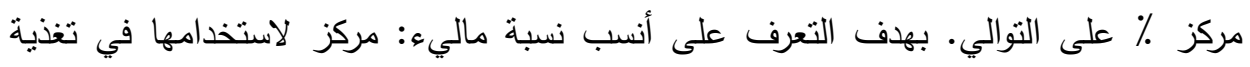

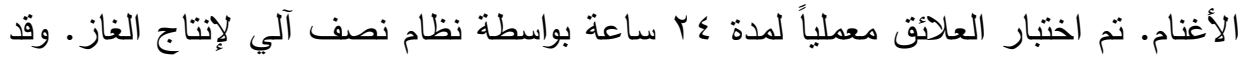

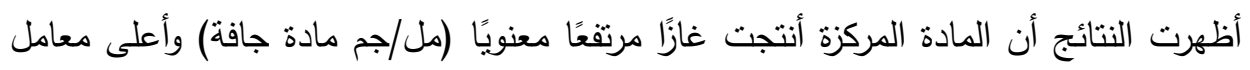

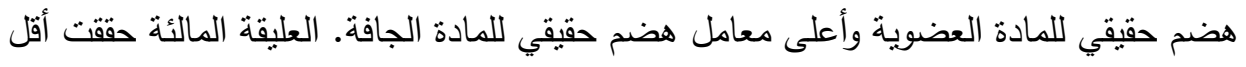

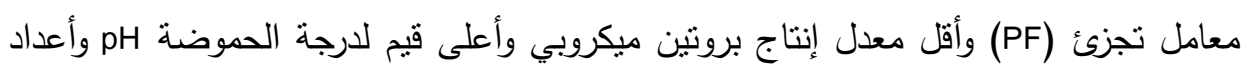

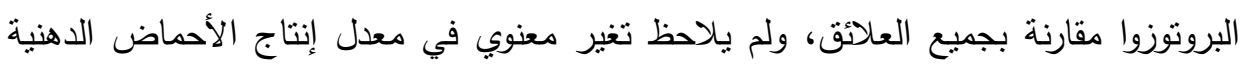

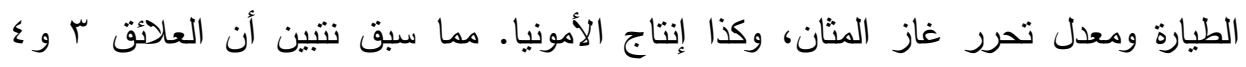

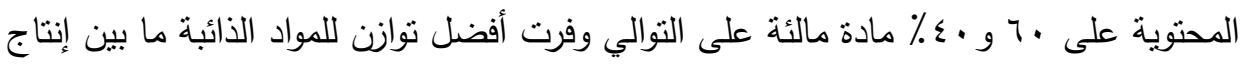

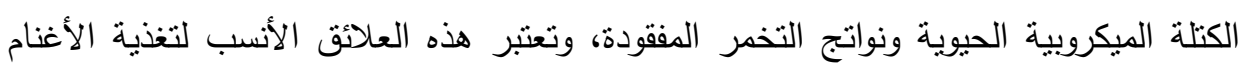
المرباة تحت الظروف البيئية والغذائية القاسية بهدف تحسين أداءها الإنتاجي. كلمات مفتاحية: إنتاج الغاز ، الميثان، علف ماليء، علف مركز ، الأمونيا. 